\title{
Elbarritasun bat duten Bigarren Hezkuntzako ikasleen jarduera fisiko eta atsedenaldietan gertatzen diren egoeren azterketa
}

\author{
Saioa Redin Azkona \\ Jarduera Fisikoan eta Kirol Zientzietan Graduatua \\ Hezkuntza eta Kirol Fakultatea \\ Euskal Herriko Unibertsitatea (UPV/EHU) \\ Xabier Iantzi Irigoien \\ Gorputz eta Kirol Hezkuntza Saila \\ Hezkuntza eta Kirol Fakultatea \\ Euskal Herriko Unibertsitatea (UPV/EHU)
}

DOI: $10.1387 /$ tantak.16344

GAKO-HITZAK: integrazioa, behar bereziak, harremanak, motor egoerak.

\section{SARRERA}

Behar bereziak dituzten haurren inklusioak garrantzi handia dauka (Eusko Jaurlaritza, 2012, Martínez Dominguez, 2005). Parte-hartzea (bizi egoeretako inplikaziotzat hartuta), aisialdia eta dibertitzeko jarduerak barne hartuta, ongizate emozionalari, erlazio sozialei eta konpetentzien garapenari lotuta dago. Aisialdiak oso efektu positiboa dauka behar bereziak dituzten pertsonengan. Autoestimua hobetzen du, interakzio soziala laguntzen eta etxean eta gizartean aurrera egiteko konpetentzia eta gaitasunak lortzeko aukera ematen du (Badía Corbella et al., 2009).

Elbarritasunen bat duten haurren familiek diotenez, Haur Hezkuntzan eta Lehen Hezkuntzan zehar, haur guztien arteko erlazioak estuak eta maiztasun handikoak izaten dira (Badía Corbella et al., 2009). Bigarren Hezkuntzan, berriz, behar bereziak dituzten gazteek ez dute haien klase-kideekiko harremanik, ez dute lagunik, ez dute gelakideen aisi jardueretan parte hartzen eta inguruarekiko egokitze gaitasunetan zailtasunak erakus- 
ten dituzte (Badía Corbella et al., 2009). Elbarritasunik gabeko pertsonekin alderatuak izan zirenean, bakardade maila altua, lagun falta eta hauekin egoteko aukera gutxi agertu zituzten (Badía Corbella et al., 2009). Zoritxarrez, patroi hau eskola adinetan hasten da (Badía Corbella et al., 2009).

Ariketa fisikoak elbarritasunak dituzten haur eta gazteengan dituen ondorio osasungarriei dagokienez ikerketa gutxi aurki daitezke. Haur eta gazteengan ariketa fisikoak dituen onurak aztertzerako orduan, zenbat eta gehiago egin orduan eta onura handiagoak lortzen direla ondorioztatu da (Janssen et al., 2010). Hala eta guztiz ere, jarduera fisiko kopuru txikiek ere onura esanguratsuak izan ditzakete osasun egoera larriak dituzten gazteengan. 5-17 urte bitarteko haur eta gazteek, eguneko 60 minutuko gutxieneko jarduera fisikoa egin beharko lukete (Janssen et al., 2010). Osasun onura esanguratsuak lortzeko, ariketa fisikoa intentsitate ertainean egin behar da, nahiz eta intentsitate altuko jardueren bidez onura handiagoak lor daitezkeen. Haur eta gazteen artean, ariketa aerobikoan oinarritutako jarduerek osasun onura handienak ematen dituzten hezurren osasunerako izan ezik, zeinetarako inpaktu handiko ariketen praktika beharrezkoa den (Janssen et al, 2010). Hori dela eta, pertsona hauek ariketa aerobikoa egin beharko lukete batez ere, astean hirutan gutxienez, gihar eta hezurrak indartzeko ariketekin konbinatuta (Janssen et al., 2010).

Behar bereziak dituzten pertsonek ariketa fisikoaren bidez lor ditzaketen onuren inguruan ere ikerketa gutxi dago. Pertsona guztiengan bezala, ariketa fisikoa egiteak gaixotasun kardiobaskularren kontrako efektuak izaten ditu. Hala eta guztiz ere, elbarritasunen bat pairatzen duten pertsonek, malgutasun eta erresistentzia entrenamenduekin lortzen dituzte onura handiena; izan ere, abilezia hobetzen eta eguneroko jarduerak egiten laguntzen diete (Cooper et al., 1990).

Pertsona hauentzat prestaturiko jarduera fisikoak indibidualizatua izan behar du, baina antzeko kategoriak hartu beharko dira kontuan: osasunaren hobekuntza bihotz-biriketako lanaren bidez, obesitatea gutxituz, gihar indar eta erresistentzia handituz eta malgutasuna landuz. Jarduera fisikoak eman ditzakeen beste onura batzuk hauek dira: autoestimuaren hobekuntza, integrazio soziala eta abilezia soziala zein talde abileziak ikastea (Cooper et al., 1990).

Ikerketa honen hurbileko lan bakarrak heziketa fisikoko klaseen ingurukoak dira (Moreno Murcia et al., 2008; Prieto Saborit et al., 2009; Sanchez-Alcaraz et al., 2013; Serrano Ruiz et al., 2013). Argi dago oso garrantzitsua dela klase hauetan gertatzen diren egoerak aztertzea; izan ere, irakasle askok zailtasunak izaten dituzte klaseetan behar bereziak dituzten ikasleen inklusioa bermatzen. Hala ere, klase zuzenduetan suertatzen diren egoerak irakasleen kontrol eta gidaritzapean gertatzen dira. Atsedenaldian berriz egoera libreak sortzen dira. Nahiz eta irakasle batzuen kontrola eman, ikasleek gustukoen dituzten jarduerak egin ditzakete, eta horretaz gain, haiekin jolasean arituko diren eta ez diren lagunak hautatu. Egia 
da ikasleen jostaldietan gertatzen diren egoerak aztertzen dituzten artikuluak badirela (Abraldes Valerias et al., 2008 ; Cantó Alcaraz et al., 2005; Chaves Álvarez, 2013; García Rodriguez et al., 2010; Máximo, 2008; Vila Diaz, 2010) baina ez dugu ikasle elbarrien jostaldiak aztertzen dituen artikulurik aurkitu.

Ikerketa honen bidez lortu nahi izan ziren helburuei dagokienez, ondorengoak dira garrantzitsuenak:

- Elbarritasunen bat zuten ikasleek jarduera fisikoa egiteko zituzten ohiturak aztertzea.

- Behar bereziak zituzten ikasleek atsedenaldietan gogoko zituzten jarduerak ezagutzea.

- Gazte hauek errealitatean atsedenaldietan egiten zituzten jardueren izaera aztertzea.

- Elbarritasunen bat zuten gazteen eta gainontzeko ikasleen artean izaten ziren harremanak aztertzea.

- Ikasle hauen eta jostaldietan zaintzan egoten ziren irakasleen artean izaten ziren harreman eta egoerak aztertzea.

\section{METODOA}

\section{Partaideak}

Gasteizko institutu publiko batean egindako ikerketa deskriptibo kuantitatibo-kualitatiboa da hau. Ikastetxearen hautaketa ausaz egin zen, betiere Derrigorrezko Bigarren Hezkuntzako ikasleak zituela bermatuz.

Ikerketa gauzatzeko, behar bereziak zituzten 11 ikasleren kolaborazioa izan genuen ( 8 neska eta 3 mutil). Ikasle hauek 14-21 urte bitarteko adina zuten eta klaseak aurrera eraman ahal izateko bi gelatan banatuta egoten ziren. Partaideen batez besteko adina 16,36 $\pm 2,15$ urtekoa zen. 14-16 urte bitarteko ikasleak ( $n=5)$ Gela Egonkorraren parte ziren, haien beharretara moldatzeko prestaturiko gela. Honetan bakoitzaren beharretara egokitutako curriculuma eskaintzen zitzaien (Eusko Jaurlaritza, 1998). 16-21 urte bitarteko ikasleak, berriz, $(n=6)$, Zereginen Ikaskuntzarako Gelan zeuden. Ikasleak bizitzan heldutasunez jokatzeko prestatzen zituzten bertan (Eusko Jaurlaritza, 1998).

Gazteek zituzten elbarritasunen artean hauek ziren: Garapenaren nahaste orokorra, Joubert sindromea, adimen-urritasuna, atzerapena, Autismoa, Autismoaren espektroko nahasmena, X hirukoitzaren sindromea, $\mathrm{X}$ hauskorraren sindromea eta Down sindromea.

Esan beharra dago ikerketa gauzatzeko orduan Datuak Babesteko Legea bete zela. Lehenengo unetik ikastetxe, ikasle, zein gurasoen baimena eskatu eta ziurtatu zen. Datuak tratatzeko orduan ikasle bakoitza zenbaki baten bidez kodifikatu zen, konfidentzialtasun osoa gordetzeko. 
Horretaz gain, informazioa esklusiboki ikerketarako datuak lortzeko erabiliko zela bermatu zen.

\section{Prozedura}

Ikerketa martxoaren bigarren erdialdean egin zen. Hasiera batean, gazteei pasatuko zitzaizkien bi galdeketa prestatu ziren, bi gai nagusi ardatz harturik: gazteek jarduera fisikoa egiteko duten ohitura eta atsedenaldian gustuko dituzten eta gustuko ez dituzten gauzak. Bi hauek prestatzerako orduan ezagunak eta erabiliak diren beste galdeketa batzuk pasarazi ziren. Ulermen erraztasuna bermatzeko, galdeketak euskaratu egin ziren. Aipatutako lehenengo galdeketarako, «Cuestionario de actividad física para adolescentes (PAQ-A)» erabili zen. Galdeketa honen fidagarritasunaren inguruan egindako ikerketa batean (Martínez-Gómez et al., 2009), galdeketa honek fidagarritasun eta baliagarritasun egokiak aurkezten zituen Espainian nerabeengan jarduera fisikoa baloratzeko. Gazteei pasatako beste galdeketa prestatzerako orduan, Chaves-ek (2013) argitaratutako artikuluan agertzen ziren arloak erabili ziren. Honetan gazteek atsedenaldietan gogokoen zituzten eta gutxien gustatzen zitzaizkien bost jarduera aukeratu behar zituzten, eta batetik bostera zenbakituz ordenatu.

Aipatutako galdeketez gain, atsedenaldien behaketarako bi erregistro fitxa diseinatu ziren. Hauetako bat ikasleek atsedenaldietan egindako jardueren erregistrorako erabili zen. Honetan, data, egindako jardueraren izena, harreman mota (psikomotor edo sozio-motorra eta kolaborazio edo oposiziozkoa), parte-hartzaile kopurua, erabilitako materiala, kideengana nor hurbildu den, haserrerik gertatu den, emaitzak, parte-hartze maiztasuna, oharrak eta jarduerak iraun duen denbora erregistratu ziren. Beste erregistro fitxa gazteek irakasleekiko zuten harremana aztertzeko erabili zen. Honek data, parte-hartzaile kopurua, nor hurbildu den norengana, arrazoia eta emaitzak biltzen zituen.

Datuen bilketari hasiera emateko, bi talde hauen irakasle arduradunek klase ordu batean geratzeko aukera eman zuten. Adostutako egun eta orduan irakasleen laguntzaren bitartez galdeketak pasatu zitzaizkien. Lehenik eta behin, galdeketak Gela Egonkorreko partaideei pasatu zitzaizkien. Gela honetan ikasle bakoitzeko irakasle bana zegoenez, ez zen inolako arazorik izan galderak ulertu zirela ziurtatzeko. Zereginen Ikaskuntzarako Gelan, berriz, laguntzarako irakasle bakarra zegoen, eta klase honetako sei ikasleek galderak modu egokian interpretatu zituztela ziurtatzeko zailtasun handiagoak izan ziren. Esan beharra dago bi klaseetan ikasleek galderak beraien kabuz irakurri eta erantzuten zituztela, baina hauen interpretaziorako irakasleen laguntza jasotzen zuten.

Aurreko paragrafoan aipaturiko erregistro fitxak betetzeko, zortzi atsedenaldi aztertu ziren, eta hauen barnean 34 egoera erregistratu ziren. Adin 
ezberdinetako ikasleak biltzen zituzten bi klaseek jostaldiak ordutegi ezberdinean izaten zituztenez gero, datuen bilketa erraztu egin zen. Normalean, atsedenaldi batean elkarrekin egoten ziren ikasle kopuruaren arabera, 2-5 ikaslek egindako jarduerak aztertzen ziren atsedenaldi bakoitzeko.

\section{Analisi estatistikoa}

Datuen analisi estatistikorako Statistical Package for Social Sciences programa (SPSS ${ }^{\circledR}$ Inc, 20. bertsioa Chicago, IL, AEB.) erabili zen. Honen bitartez, aztertu nahi ziren datu guztien portzentaje eta maiztasunak atera ziren. Honetaz gain, bi aldagai ezberdinen konparaketa egiteko orduan gertagarritasun taulak ere erabili ziren.

\section{EMAITZAK}

\section{Helburua: Elbarritasunen bat zuten ikasleak jarduera fisikoa egiteko zituzten ohiturak aztertzea.}

Lortutako emaitzen analisiarekin hasteko, praktika ohiturei buruz egindako galdeketan zentratuko gara. Honen arabera, aztertutako 11 ikasleen artean 9k hartzen zuten parte heziketa fisikoko klaseetan. Parte hartzen zutenen artean, 1. irudian ikus dezakegun bezala, ikasleak oso gutxitan (\% 40etan) sentitzen ziren oso aktibo klase hauen barnean.

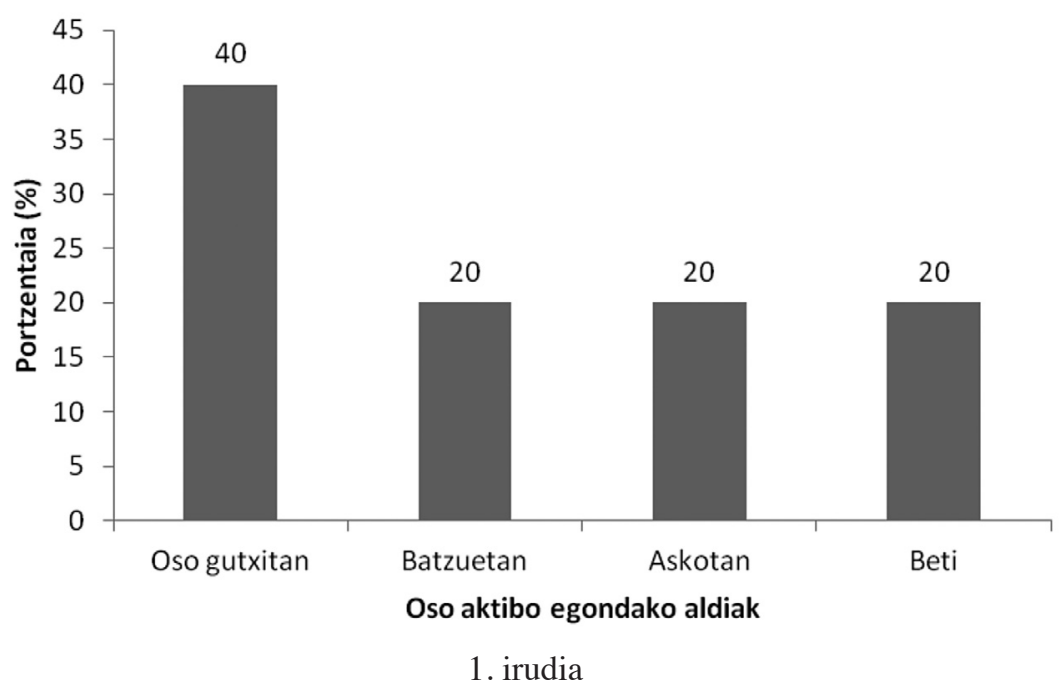

Azken 7 egunetan heziketa fisikoko klaseetan oso aktibo egondako aldiak 


\section{Helburua: Behar bereziak zituzten ikasleek atsedenaldietan gogoko zituzten jarduerak ezagutzea}

Aztertutako gazte hauei atsedenaldietan gehien gustatzen zitzaizkien jarduera edo faktoreak 2. irudian ikus daitezke. Honen arabera, lagunekin egotea da gazteek gustukoen duten jarduera. Atsedenaldietan gutxien gustatzen zitzaienari buruz galdetu zitzaienean, berriz, jostaldia motzegia egiten zitzaiela izan zen (\%40). Hala eta guztiz ere, galdera hau egiterakoan jasotako bigarren erantzun nagusia «dena gustatzen zait» izan zen, \%30eko balioarekin.

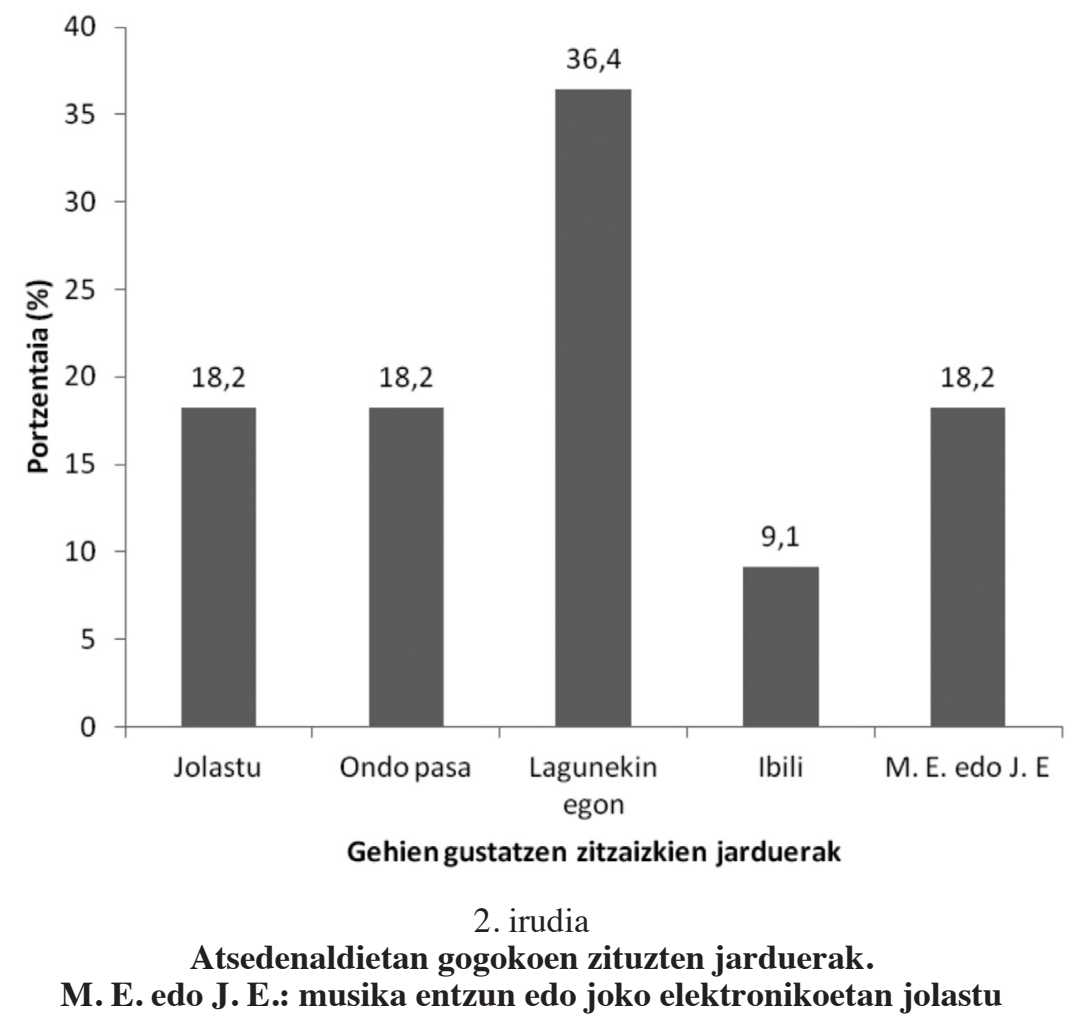

\section{Helburua: Gazte hauek errealitatean atsedenaldietan egiten zituzten jardueren izaera aztertzea}

Erabilitako erregistro fitxari dagokionez, gazteek atsedenaldi gehienetan egiten zuten jarduera ibiltzea izan zen (\%88,2ko balioarekin), bakarka, 
beste norbaitekin hizketan edota elkarrekin abestiak kantatu eta asmatzen. Datu hauek 3. figuran azter ditzakegu. Ibiltzeaz gain, oso jarduera gutxi egiten dituzte atsedenaldietan. Hitz egin eta futbola ikusteaz aparte, ez dute inolako jarduerarik egiten.

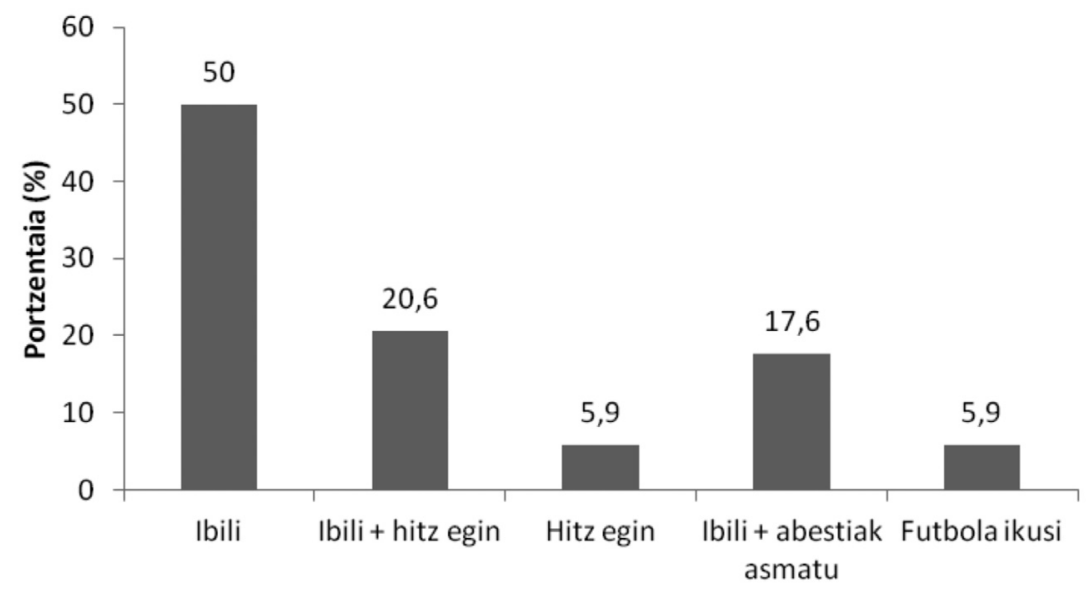

Atsedenaldietan praktikatutako jarduerak

3. irudia

Gazteek atsedenaldietan gehien egindako jarduerak

\section{Helburua: Elbarritasunen bat zuten gazteen eta gainerako ikasleen artean sortzen ziren harremanak aztertzea}

Gazteek atsedenaldietan egindako jardueretan sortutako harremanei dagokienez, gehienetan sortu ziren harremanak sozio-motorrak izan ziren (\%73,3ko balioarekin). 1. taulan ikus daitekeen bezala, aztertutako ikasle baten eta institutuko gainerako ikasle batzuen arteko haserre egoera bakar bat gertatu zen.

1. taula

Gazteek atsedenaldietan egindako jardueretan sortutako harremanak

\begin{tabular}{l|lrc}
\hline \multicolumn{2}{c}{ Harreman mota } & Maiztasuna & $\begin{array}{c}\text { Portzentajea } \\
(\%)\end{array}$ \\
\hline Psikomotorra & Osotara & 9 & 26,5 \\
\hline \multirow{3}{*}{ Sozio-motorra } & Osotara & 25 & 73,5 \\
& Egoera positiboak & 24 & 70,6 \\
& Haserreak & 1 & 2,9 \\
\hline
\end{tabular}


Aurreko taulari jarraiki, ikasleak, jostaldietan jarduera sozio-motorrak egiten zituztenean, binaka elkartzen ziren nagusiki (\%48ko portzentajearekin). Hala ere, seiko taldeetan elkartzea ere nahiko ohikoa dela ikus dezakegu.

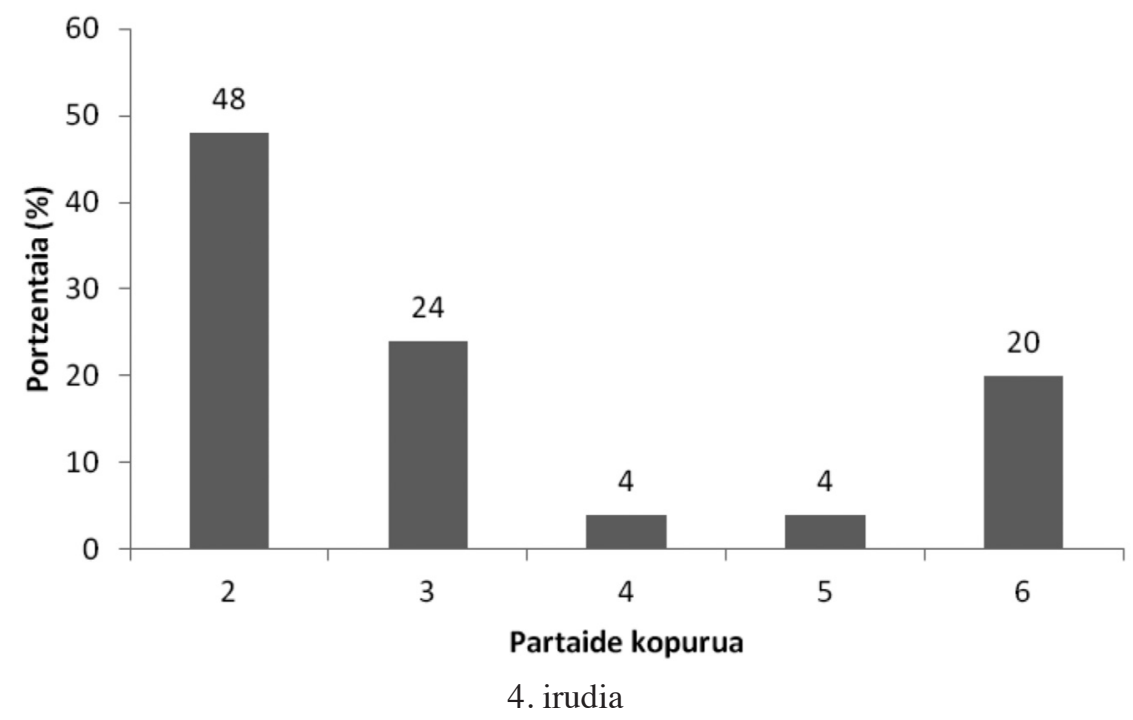

Atsedenaldian egoera sozio-motorretan elkartutako taldekide kopurua

Jasotako datuei erreparatuta, beste gazteengana hurbiltzen zen pertsonaren arabera, haserreak sortzen ziren edo ez aztertu genuen. Haserre egoera bat gertatu zela ikustean, interesgarria iruditu zitzaigun elbarritasuna zuen ikasleetako bat besteengana gerturatzean sortu zela aipatzea, eta ez alderantziz.

Beste alde batetik, 5 . irudian ikus daitekeen bezala, ikasleak atsedenaldira elkarrekin atera ziren bakoitzean emaitza onak izan ziren (ikasle guztiak pozik zeuden). Kideak hurbiltzen zirenetan ere, kasu gehienetan pozik egoten ziren, nahiz eta kasu batean deserosotasun egoera bat sortu. Elbarritasunen bat zuten ikasleak besteengana hurbildu ziren kasuetan, ordea, hirutan egoera deserosoak izan ziren eta horietako batean serio eta haserre bukatu zuten. 


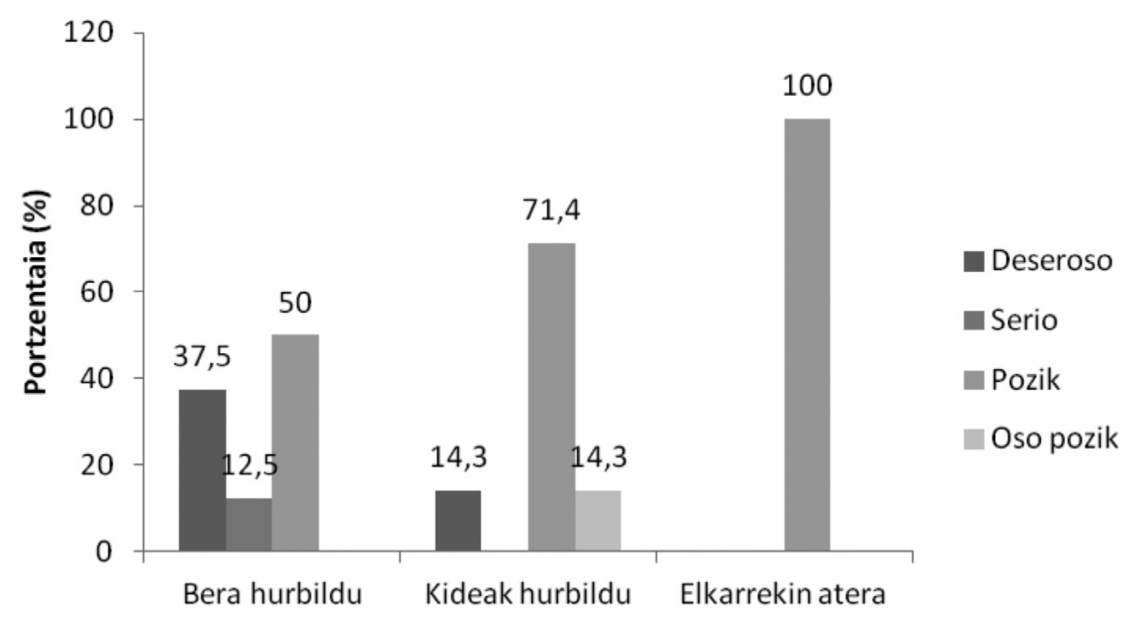

Hurbildu den pertsonaren arabera emandako emaitzak

5. irudia

Besteengana hurbildu den ikaslearen arabera izandako emaitzak

\section{Helburua: Ikasle hauen eta jostaldietan zaintzan egoten ziren irakasleen artean sortzen ziren harreman eta egoerak aztertzea}

Ikasle-irakasle artean izan ziren erlazioak aztertzerakoan, kasu gehienetan hurbiltzen direnak irakasleak zirela ikusi zen. Ikasle eta irakasleak elkarrekin egon zirenetatik bitan elkarrekin atera ziren klasetik. Egoera batean ikaslea irakaslearengana hurbildu zen arren, hamar egoeratatik bitan irakasleak izan ziren ikasleengana hurbildu zirenak.

Aipatutako irakasle hurbiltze hauek gertatzean, egoeren \%63,3a itxuraz arrazoi berezirik gabe sortu zen. Hurbiltzeen $\% 18,2 \mathrm{a}$, berriz, ikasleak haien gelako gainerako ikasleengana gerturatzeko helburuarekin egin zen. Azkenik, irakaslearen zain egotea eta gazteen artean gatazkak sortzea izan ziren elkarrengana hurbiltzeko arrazoiak, bakoitza \%9,1eko balioarekin. Emaitzei bukaera emateko, ikasle eta irakasleak elkarrengana hurbiltzean izandako emaitzei erreparatu zaie. 6. irudian ikus daitekeen bezala, \%44,4ko proportzioan ikasle eta irakasleak elkartzean, elkarrekin jarraitzen zuten hizketan atsedenaldian zehar. 


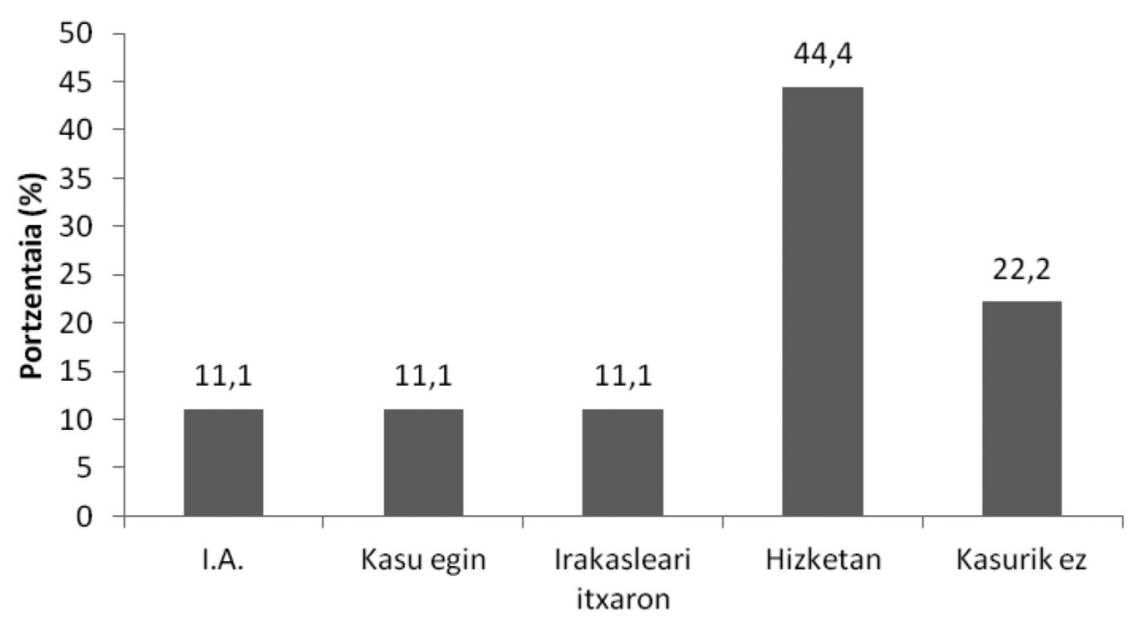

Irakasle-ikasleak elkarrengana hurbiltzean emandako emaitzak

I.A.: irakaslearengandik aldendu.

6. irudia

Irakasle eta ikasleak elkarrengana hurbiltzean emandako emaitzak

\section{EZTABAIDA}

Egindako ikerketaren bidez lortu nahi izan zen helburu hauxe izan zen: Derrigorrezko Bigarren Hezkuntzako ikastetxe publiko batean ikasle elbarriek jostaldietan zituzten ohiturak aztertzea izan zen, gazte hauek egiten zituzten jarduerak, haien gelakideekin izaten zituzten harremanak eta irakasleekiko harremanak ikusiz. Atsedenaldietan gertatzen diren egoera hauek aztertzea oso garrantzitsua izan daiteke behar bereziren bat duten ikasleek bizi dituzten egoerak ikusteko; izan ere, egoera hauek ez dira irakasleen erabateko kontrolpean egoten. Ikerketa honekin lortutako emaitzen artean aipagarriena hau da: nahiz eta lagunekin egon, jolastu eta ondo pasatzea gustukoen zituzten jardueren artean egon, errealitatean gehien egindako jarduera jolastokian ibiltzea izan zela. Irakasleekiko erlazioari dagokionez, irakasleak izaten ziren ikasle hauengana gehien hurbiltzen zirenak.

Heziketa fisikoko klaseetan parte hartzen zuten galdetu zitzaienean, 11 ikasleetatik bederatzik hartzen zuten parte klase hauetan. Horretaz gain, ikasle hauen artean \%40ak oso aktibo egondako aldiak oso gutxi izaten zirela aitortu zuen. Prieto Saborit-en (2009) arabera, aktibotasun falta horren arrazoi nagusia izan daiteke klase hauetan egindako jarduerak hein handi batean lehiakorrak izaten direla. Jarduera hauen bidez, ikasleen artean sortzen diren motrizitate eta kondizio fisikoari dagozkion aldeak azpimarratu 
egiten dira, eta horrek esperientzia motor, abilezia eta egoera fisiko okerragoak dituzten ikasleek motibazioa galtzea dakar (Prieto Saborit, 2009). Ikasle hauen motibazioa handitu nahian, Prieto Saborit-ek (2009) jarduera lehiakor eta indibidualisten ordez jarduera kooperatiboak kontrolarekin eta hauen ebaluaziorako erabiliko den erregistro batekin egitea proposatzen $\mathrm{du}$, hauen funtzionamendu egokia bermatzeko. Aipatutako ikerketa honetan, jarduera kooperatiboak landu zirenean, taldearen motibazioa modu esanguratsuan handitu zen (Prieto Saborit, 2009). Beraz, gorputz hezkuntzako irakasleek kontuan hartu beharko lukete zein ekintza mota proposatzen dituzten klaseetan ikasle guztiak aktibo daudela bermatzeko.

Ikertutako ikasle taldeak jostaldietan gustuko zituzten jarduerak eta benetan egiten zituztenak alderatzerakoan, ezberdintasun handiak topatu dira. Nahiz eta gustukoen zuten jarduera lagunekin egotea izan (egoera errealetan gehienetan betetzen den baldintza), jolastea, dibertitzea eta musika entzutea edo joko elektronikoetan jolastea izan ziren bigarren postua bete zutenak. Emaitzen arabera, nahiz eta hauek izan gustukoen zituzten jarduerak, jostaldietan gehienetan errepikatutako jarduera ibiltzea izan zen. Hau horrela izanik, gazteek oso gutxitan egiten zituzten gustuko zituzten jarduerak. Chaves Álvarez-ek (2013), elbarritasunik gabeko haur eta gazte jostaldietan gogoko zituzten jardueren inguruan egindako ikerketan jolastu, jan, ondo pasa, deskantsatu eta lagunekin egon izan ziren lortutako emaitzak, hurrenez hurren. Ikerketa honetan ere, haurrek gustukoen zituzten jolasak aipatzen zituzten. Gure ikerketan ez bezala, haurrek jolasak egiten zituzten gehienetan, eta zortzigarren postuan agertzen da, korrika ibiltzea eta harrapaketetan jolastearekin batera (Chaves Álvarez, 2013). Beste ikerketa batean aipatzen denez, behar bereziak dituzten ikasleekiko jarrera negatiboa da komunitateko aisialdi jardueretan, pertsona hauen parte hartzea eragozten zuena (Gutiérrez San Martin et al., 2006). Arrazoi hau izan daiteke ikerketa honetan aztertutako atsedenaldietan ere gazte hauen parte hartzea saihestu duena.

Gazteek atsedenaldietan egindako jarduerak gehienbat sozio-motorrak izan ziren. Jarduera hauetan sortutako erlazio gehienak positiboak izan ziren; hala ere, erlazio negatibo bat ere izan zen (ikasle batzuen arteko haserrea). Ikertzaile batzuen arabera, gazteentzat gelakideekin erlazionatu eta jolasteko duten eguneko memento bakarra izan daiteke (Vila Díaz, 2010). Ikasleek abilezia sozial, emozional, fisiko eta kognitiboak gara ditzakete memento hauetan (Vila Díaz, 2010). Hori dela eta, oso garrantzitsua da ikasleek gelakideekin harremanak izan ditzaten eta egoera psikomotorrak ahalik eta gehien murritz daitezen. Euskal Autonomi Erkidegoko (EAE) ikastetxe askok elkarbizitza planetan jolastokietan jolas kooperatiboak antolatzea proposatzen dute. Garrantzitsua izan daiteke epe motz edo luzean plan hauen eragina zein den jakitea. Gure ikerlanean, aztertutako kasu gehienetan, ikasleak egoera sozio-motorretan egon direnetan binaka edo hirunaka elkartzen ziren, seiko taldeetan elkartzea ere nahiko ohikoa dela 
ikus dezakegu. Horrek lotura zuzena izan dezake aztertutako taldeetako batean sei ikasle izatearekin. Ikasle hauek gela barrutik elkarrekin atera eta talde bera gordetzen zuten atsedenaldian. Talde hauek, kasu batean izan ezik, elbarritasuna zuten ikasleek osatzen zituzten; hau da, elbarritasuna zuen ikasle bakar batek zuen elbarritasunik gabeko beste ikasleekin elkartzeko ohitura. Gainerako gelakideak elbarritasunik gabeko gazteekin elkartuz gero, egoera puntualetan elkartzen ziren eta oso denbora tarte laburrerako. Ikastetxearen aldetik, ikasle guztiak elkarrekin egoteko programaren bat bultzatzea onuragarria izan zitekeen, egoera hauek saihestu eta aniztasunaren bidean laguntzeko. Helburu hau lortzeko, ikastetxeek ikasketa kooperatiboa bultzatu beharko lukete. Prozesu honetan ikasleek elkarren laguntzaren beharra dute haien helburuak lortu ahal izateko (Prieto Saborit, 2009). Metodologia hau lortzeko, ezaugarri batzuk hartu beharko dira kontuan (Chaves Álvarez, 2013):

- Interdependentzia positiboa: parte-hartzaile guztien esfortzua ezinbestekoa da taldearen arrakasta lortzeko. Irakasleak, rolen bitartez, interdependentzia hau positiboa izan dadin lortu behako du.

- Bakarkako erantzukizuna: taldearekiko erantzukizuna. Bakoitzaren lanaren garrantzia taldean.

- Interakzio eragilea: taldekideek besteen esfortzuak estimulatu eta lagundu behar dituzte.

- Erlaziozko abileziak: taldekideek elkar ezagutu eta errespetatu behar dute, taldean konfiantza izan eta talde lanerako oinarrizko arauak eratu.

- Talde prozesua edo auto-ebaluazioa: ikasleek egindakoaren inguruan gogoeta egiten, egindako jarduerak baloratzen, haien portaerak eta hauen ondorioak aztertzen ikasi behar dute. Honek hobekuntzak lortzen lagunduko die.

Jarduera hauen bitartez, ikasleen erlazioak hobetu eta irakasleekiko dependentzia gutxitzea bilatzen da, joko kooperatiboen bitartez gazteen aktibitatea areagotuz eta egoera psikomotorrak ahalik eta gehien murriztuz.

Aztertutakoaren arabera, gelakideak atsedenaldira elkarrekin ateratzen zirenean emaitzak beti onak izaten ziren eta ikasle guztiak pozik egoten ziren. Elbarritasunik ez zuten ikasleak aztertutako ikasleengana hurbiltzen zirenean, berriz, nahiz eta kasu gehienetan pozik egon, kasu batean oso pozik egon ziren eta beste batean deserosotasun egoera bat gertatu zen. Elbarritasuna zuten ikasleak besteengana hurbiltzen zirenean, berriz, kasu askotan pozik egon arren beste batzuetan deserosotasun eta seriotasun egoerak sortzen ziren. Sozialki, egoera hauek guztiak gertatzeak onura handiak ematen dizkie gazte hauei; izan ere, egoera hauei esker ikasleek besteekin gauzak partekatzen, kooperatzen, komunikatzen, ezarritako arauak betetzen eta auto-diziplina ikasten dute (Vila Díaz, 2010). Hauekin batera onura emozionalak ere izaten dituzte (Vila Díaz, 2010). Ikasleek estresa 
kudeatzeko metodo erabilgarriak barneratzen dituzte (Vila Díaz, 2010). Ikaskideekin izandako gidarik gabeko interakzioaren bidez ikasleek autonomia ere hobetzen dute, haien abileziak, jarraikitasuna, auto-zuzendaritza, erantzukizuna eta auto-onespena hobetzearekin batera (Vila Díaz, 2010). Interakzio mota honek izaeraren garapena bultzatzen du, bai erabaki moral hobeak hartzerako orduan eta baita banakako erantzukizun sozialaren kontzientzia hobetzeko ere (Vila Díaz, 2010).

Irakasleekiko harremana aztertu zenean, irakasleak izaten ziren kasu gehienetan ikasleengana hurbiltzen zirenak, eta gehienetan arrazoi berezirik gabe gertatzen zen. Kasu gutxi batzuetan, taldeak elkarrekin segitzeko edo gatazkaren bat sortu zelako izan zen. Kasu hauetako gehienetan, irakasle eta ikasleak elkarri hurbiltzean elkarrekin geratzen ziren atsedenaldian. Beste kasu batzuetan, ikasleek ez zieten irakasleei jaramonik egiten eta gainerako kasuetan irakaslearen zain egon, kasu egin edo irakaslearengandik aldentzen ziren. Eguneko gainerako uneekin alderatuz gero, jostaldia da elbarritasunik gabeko haurrek askatasun gehien izaten duten garaia haiek nahi dutena eta nahi dutenekin egiteko (Chaves Álvarez, 2013). Chavesen (2013) arabera, jostaldiak modu egokian gainbegiraturik egon behar du, heldu adituen bitartez. Eraso eta jokabide erasotzaileak ezin dira onartu eta irakasleek ikasleen segurtasun fisiko edo emozionala arriskuan dagoenean esku hartu egin beharko dute (Chaves Álvarez, 2013). Horretaz gain, irakasleek gaitasun sozialen garapena bultzatu beharko dute atsedenaldian zehar: kooperazioa eta gatazken ebazpena, adibidez (Chaves Álvarez, 2013). Hau horrela izanik, irakasleek une puntualetan hartu beharko lukete parte, ikasleei behar duten askatasuna ere emanez. Chaves Álvarezek (2013) egindako ikerketaren arabera, ikasle gehienek atsedenaldietan gehienetan egiten dutena hamaiketakoa egin eta haurrak zaintzea da. Hala ere, ikerketa honetan lortutako emaitzak kontuz interpretatu behar dira. Alde batetik, ikastetxe batean bakarrik egindako ikerketa bat delako eta lagin txikia delako. Beste aldetik, erabilitako galdetegiaren ( Cuestionario de actividad física para adolescentes (PAQ-A)») euskarazko bertsioaren baliagarritasuna eta fidagarritasuna ez dago frogatuta. Oso garrantzitsua da ikerketa gehiagoren bidez elbarritasunak dituzten ikasleen harremanak eta egoera hobetzeko ikastetxeetan bultza daitezkeen politikak aztertzea.

\section{ONDORIOAK}

Ikertu denaren arabera, ikasleek nahiz eta beste mota bateko jarduerak nahiago dituzten, paseatzen pasatzen dituzte jostaldi gehienak. Egoera hauek saihesteko eta ikasleek gustuko jarduerak egitera bultzatzeko saioa egin beharko litzateke. Horretaz gain, egoera psikomotorren kopurua nahiko handia da, ikasleek atsedenaldiak lagunekin erlazionatzeko baliatu beharko lituzketela kontuan hartuta. Honi lotuta, institutuko beste ikasle 
batzuek behar bereziak dituzten ikasleei ematen zizkieten erantzun txarrak desagerrarazteko helburua bermatu beharko litzateke kasu batzuetan izandako erreakzio txarrak saihesteko. Azkenik, irakasleek egoera batzuetan erakutsitako gehiegizko kontrola ere saihestu beharko litzateke gazteen erabakiak hartzeko ahalmena lantzeko eta nahi duten ikasleekin joan ahal izateko, gustukoen dituzten jarduerak egitera.

Jolastea atsedenaldian gustuko duten jarduera denez gero, ikastetxeek jarduera kooperatibo libreak proposatu beharko lituzkete. Honetarako, ikasleek gustuko dituzten jarduerak aztertu, haientzako espazio hezigarriak bultzatu eta beraien interes eta beharretara moldatzen diren jokoak proposatu beharko lituzkete. Aipatutako jarraibideek, irakasleek ikastetxeetan hartu beharko lituzketen erantzukizunak bermatzen dituzte. Horrela, irakasleek gazteentzako espazio seguru eta zainduak bermatuko dituzte, eta aldi berean atsedenaldiaz modu hobean gozatzeko aukera emango diete.

The aim of this study was to analyze the physical activity habits, the favorite activities during the school breaks, the nature of the activities practiced during the school breaks, the relationship of the teachers and students of the Secondary students with disabilities. In this study participated 11 secondary school students with special needs ( 8 girls and 3 boys). These students were aged between 14-21 years of old. According to the results of this study, even be friends, they like to play and have fun in the activities, the most practiced activity in reality he was walking through the courtyard of the students had a disability. Disability in their students during the breaks one of the most socio-engines were practiced. Regarding the relationship with teachers, most of who come to the students who were teachers. skills.

Key words: integration, special needs, human relations, motor

El objetivo principal de este estudio fue analizar los hábitos de práctica de actividad física, las preferencias y el tipo de actividades realizadas y las relaciones con otros compañeros y profesores en los recreos escolares en alumnos de educación secundaria con algún tipo de discapacidad. En este estudio participaron 11 alumnos con discapacidad (8 chicas y 3 chicos) de entre 14 y 21 años. Atendiendo 
a los resultados obtenidos, a pesar de que los participantes en este estudio afirmaban que lo que más les gusta realizar en los recreos era estar con los compañeros, jugar y pasárselo bien, en la observación directa realizada, la actividad más frecuente no fue la de jugar sino la de pasear. Por otro lado, la actividad realizada por los alumnos con discapacidad de este estudio en los recreos tuvo un carácter predominantemente socio motor. Referente a la relación de los alumnos con discapacidad con los profesores en los recreos, en mayor medida fueron los profesores quienes se acercaban a estos alumnos para entablar relación.

Palabras clave: integración, necesidades especiales, relaciones, situaciones motoras.

L'objectif principal de cette étude était d'analyser les habitudes d'activité physique, les préférences et le type d'activités et les relations avec les pairs et les enseignants à la récréation de l'école des élèves du secondaire ayant une déficience. Cette étude a porté sur 11 étudiants handicapés (8 filles et 3 garçons) âgés de 14 à 21 ans. Basé sur les résultats, même si les participants à cette étude ont affirmé que la plupart de ce qu'ils aiment faire à la récréation était d'être avec ses pairs, jouer et avoir du plaisir, dans les observations directes faites, l'activité la plus commune était pas à jouer, c' est de se promené. D'autre part, l'activité réalisée par les élèves de l'étude avec étudiants handicapés avait un caractère principalement socio moteur. En ce qui concerne a la relation des étudiants handicapés et les enseignants à la récréation, dans une grande mesure ont été les enseignants qui s'ont approché ces étudiants à s'engager dans une relation.

Mots-clé: l'intégration, des besoins spéciaux, es relations, des stuations motu

\section{ERREFERENTZIAK}

Abraldes Valerias, J. A., eta Argudo Iturriaga, F.M. (2008): «Utilización del recreo escolar por niños de $4^{\circ}$ y $6^{\circ}$ de Primaria». Retos. Nuevas Tendencias en Educación Física, Deporte y Recreación, 14, 88-91.

Badía Corbella, M., eta Longo Araújo de Melo, E. (2009): «El ocio en las personas con discapacidad intelectual: participación y calidad de vida a través de las actividades de ocio». Revista Española Sobre Discapacidad Intelectual, 40(3), 231, 30-44.

Cantó Alcaraz, R., eta Ruiz Pérez, L. M. (2005): «Comportamiento motor espontáneo en el patio de recreo escolar: análisis de las diferencias por género en 
la ocupación del espacio durante el recreo escolar». Revista Internacional de Ciencias del Deporte, 1, 28-45.

Chaves Álvarez, A.L. (2013): «Una mirada a los recreos escolares: el sentir y pensar de los niños y niñas». Revista Electrónica Educare, 17(1), 67-87.

Cooper, R. A., Quatrano, L. A., Axelson, P. W., Harlan, W., Stineman, M., Franklin, B., Krause, J. S. Bach, J., Chambers, H., Chao, E. Y. S., Alexander, M. eta Painter, P. (1990): «Research on physical activity and health among people with disabilities: a consensus statement». Journal of Rehabilitation Research \& Development, 36, 2.

Eusko Jaurlaritza (1998). Normativa sobre alumnado con necesidades educativas especiales en el País Vasco. http://www.hezkuntza.ejgv.euskadi.eus

Eusko Jaurlaritza (2012). Plan Estratégico de Atención a la Diversidad en el marco de una Escuela Inclusiva. http://www.hezkuntza.ejgv .euskadi.eus

García Rodriguez, M., eta Serrano Aguilera, J.M. (2010): «La optimización del patio de recreo para favorecer la práctica de actividades físico-deportivas mediante un proyecto de convivencia». Espiral. Cuadernos del Profesorado, 3(6), 32-42.

Gutiérrez Sanmartín, M., eta Caus i Pertegáz, Nuria (2006): «Análisis de los motivos para la participación en actividades físicas de personas con y sin discapacidad». International Journal of Sport Science, 2, 49-64.

Janssen, I. eta LeBlanc, A. G. (2010): «Systematic review of the health benefits of physical activity and fitness in school-aged children and youth». International Journal of Behavioral Nutrition and Physical Activity, 7, 40, 1-16.

Martínez Dominguez, B. (2005): «Las medidas de respuesta a la diversidad: posibilidades y límites para la inclusión escolar y social». Profesorado, Revista de Currículum y Formación de Profesorado, 1(1), 1-31.

Martínez-Gómez, D., Martínez-de-Haro, V., Pozo, T., Welk, G.J., Villagra, A., Calle, M.E., Marcos, A. eta Veiga, O.L. (2009): «Fiabilidad y validez del cuestionario de actividad física PAQ-A en adolescentes Españoles». Revista Española de Salud Pública, 83, 427-439.

Máximo, D. L. (2008): «El juego durante el recreo escolar: si aprendo a comunicar, ¿puedo jugar?». Revista Educación Física y Deporte, 27(1), 87-94.

Moreno Murcia, J. A., Parra Rojas, N., eta González-Cutre Coll, D. (2008): «Influencia del apoyo a la autonomía, las metas sociales y la relación con los demás sobre la desmotivación en educación física». Psichotema, 20(4), 636-641.

Prieto Saborit, J.A., eta Nistal Hernández, P. (2009): «Influencia del aprendizaje cooperativo en educación física». Revista Iberoamericana de Educación, 49(4), 1-8.

Sanchez-Alcaraz, B.J., Gómez-Mármol, A., Valero, A., eta De la Cruz, E. (2013): «Aplicación de un programa para la mejora de la responsabilidad personal y social en las clases de educación física». European Journal of Human Movement, 30, 121-129.

Serrano Ruiz, C. P., Ramírez Ramírez, C., Abril Miranda, J. P., Ramón Camargo, L. V., Guerra Urquijo, L. Y., eta Clavijo González, N. (2013): «Barreras contextuales para la participación de las personas con discapacidad física». Salud UIS, 45(1), 41-51.

Vila Díaz, F. J. (2010): «El recreo: ¿sólo un descanso?». Pedagogía Magna, 5, 113-118. 